London, 1851-52. The only German case which I can find is one by Schwartzenberger, published in 1894. He styles it "a multilocular lympho cyst of the omentum." Besides these there are 2 other cases, 1 in the Medical Times and Gazette in 1862 and the other in the Medical Press and Circular in 1883. Mr. Alban Doran mentions, too, that there is a small omental cyst without any clinical history contained in the Museum of the Royal College of Surgeons of England.

The cyst belonging to the case which I have related, when empty and collapsed, is about as big as a large cocoanut and its walls are tough and strong. When distended with fluid at the time of the operation the walls were thin and of the bluish colour seen in an ordinary ovarian cyst. It is impossible from an examination of this cyst to say in what structure it had its origin. It is now in the Museum of the Medical Department of the Yorkshire College.

Leeds.

\section{A NEW METHOD IN SHOULDER PRESENTATIONS.}

By A. J. TURNer, M.D. DURH.

If there is one form of presentation in midwifery practice which a busy practitioner dislikes more than another to encounter I suppose it is the shoulder, especially if well advanced before it comes under his notice. I have therefore been prevailed upon to describe a method which I have made use of for the last ten years, for though happily these cases are comparatively rare it has been of great practical value in five.

In the first stage, the arm of the fotus being protruded, it is doubled at the elbow, the fingers resting on the shoulder, rforming as it were the point of a wedge which is now pushed back again into the uterus, in the interval of the pains, the rapward movement being continued by the operator's bent forefinger pressed against the shoulder. In the second stage the accoucheur's middle finger is extended and by preference placed in the mouth of the foetus or on some firm bony point of the head. Now, with the assistance of the operator's other hand external to the mother's abdomen, the head is drawn into a better position, where, should the pains still be strong, it may be left to nature, or the instruments applied if considered acivisable.

This method saves all efforts at podalic version, over-distension of the uterus by the addition of the hand (only two rfingers actually entering the uterus), as well as decapitation, \&c. It may be made use of after the arm has been prorouded for some time and takes but a few minutes to iperform.

The cases alluded to had been in hand for from one to ten thours before coming under my care and in all of them the infants have been born alive with the exception of one in which the arm had protruded for ten hours and was then quite black from congestion and in which the infant gave but a few spasmodic movements after delivery.

Bournemouth.

\section{LEAD POISONING IN AN INFANT FOUR WEEKS OLD.}

By Fredk. W. M. Stephenson, M.B., C.M. Edin.

I VENTURE to think that the particulars of this caseranique as far as my experience goes and, I believe, at least ancommon in that of others-may be of general interest. On Oct. 10th, 1898, I attended a patient in confinement. The child was well nourished and healthy and continued so until the end of my visits about a week afterwards. On Nov. 8th I was hurriedly sent for, the message stating that the infant was dying. I was informed by the mother on my arrival that the child appeared to her to be just recovering from a fit. I found the patient evidently in considerable pain, screaming violently, and with the legs flexed upon the abdomen. My first and most natural conclusion was that these symptoms indicated colic due to imperfectly digested food, but on examining the tongue $I$ noticed an unmistakeable blue line on the gums. This with a history of constipation was quite sufficient to confirm my diagnosis that lead was the cause of the trouble. The child had mever taken milk from the breast, but the feeding bottles were, I found, above suspicion, as well as the watersupply and general surroundings. Finally I discovered that the nurse, considered an experienced woman, had been freely dusting the child with a powder, procured by herself quite innocently from a local chemist, and which was shown to me in a packet bearing the label "Powdered White Lead." This had been liberally dusted about the neck and behind the ears, and consequently would at such times be freely inhaled. In addition the powder had been kept loosely upon the mantelshelf where the feeding bottle and a "dummy teat" were frequently placed.

I am pleased to be able to add that under the usual treatment, modified to suit the age, the child is making a good recovery.

Blackburn.

\section{d}

\section{HOSPITAL PRACTICE, BRITISH AND FOREIGN.}

Nulla autem est alia pro certo noscendi via, nisi quamplurimas et morborum et dissectionum historias, tum aliorum tum proprias collectas habere, et inter se comparare.-MoRgaGNI De Sed. et Caus. Morb., lib. iv. Procmium.

\section{DERBYSHIRE ROYAL INFIRMARY.}

A CASE OF CEREBRAL TUMOUR; NECROPSY.

(Under the care of Dr. G. H. MILNES.)

THE success which often attends attempts to localise cerebral tumours is remarkable, but it not infrequently happens, as in the very interesting case reported below. that the data presented by the signs and symptoms are not sufficient to allow any exact diagnosis to be made. The presence of more than one growth increases largely the difficulty; great extension of the growth has a similar effect. In the following case the most striking point is the interference by the tumours with the intracranial venous circulation, leading to dilatation of the collateral vessels. For the notes of the case we are indebted to Dr. H. M. Tickell, house physician.

A man, aged twenty-eight years, a railway guard, applied for treatment at the Birmingham Eye Hospital on May 3rd, 1897, on account of failure of sight, and on examination was found to have double optic neuritis. The first symptom noticed by him, ten weeks previously, was severe pain in the head. Shortly after this he had vomited for some weeks and had pain down the left side of the face, the pain passing off when the sight began to fail and being succeeded by numbness. The only history of previous illness obtained from him was an attack of smallpox three years previously, and syphilis was denied. On the 17th the knee-jerks were found to be exaggerated. A few days later he began to have attacks of vomiting without relation to food and he also complained of pains in the head and at the root of the nose. On June 21st he was admitted as an in-patient of the Derbyshire Royal Infirmary. It was then observed that the plantar reflexes were greatly increased. As regards vision, he had but a bare perception of light, the discs passing into atrophy. He was discharged from hospital on July 10th. There had been no headache or vomiting. since his admission and he described himself as feeling much better. On the 14th he came again to the hospital as an out-patient. The next symptom of importance which was noticed was an enlargement and varicose condition of the veins in the frontal region about the middle line. A short time afterwards a similar prominence consisting of a bunch of dilated veins appeared above the external occipital protuberance. On the occurrence of severe headache these veins were observed to become more swollen, thus indicating that the headache was due to increased cerebral pressure. On Nov. 15th he was re-admitted into the hospital. He was then quite blind from optic atrophy. There were occasional occipital headache and continual numbness of the left side of the face and all round the mouth. He also had pain.in the eyes, especially the right eye. On Dec. 4th there were 